\title{
Effects of Gum Arabic (Acacia senegal) on Renal Function in Diabetic Mice
}

\author{
Omaima Nasir $^{\mathrm{a}}$ Anja T. Umbach ${ }^{\mathrm{a}}$ Rexhep Rexhepaj ${ }^{\mathrm{a}}$ Teresa F. Ackermann ${ }^{\mathrm{a}}$ \\ Madhuri Bhandaru ${ }^{a}$ Ammar Ebrahim $^{a}$ Ferruh Artunc $^{a}$ b Daniela S. Kempe $^{a}$ \\ Goverdhan Puchchakayala ${ }^{a}$ Balasaheb Siraskar ${ }^{\mathrm{a}}$ Michael Föller $^{\mathrm{a}}$ Amal Saeed $^{\mathrm{c}}$ \\ Florian Lang ${ }^{\text {a }}$
}

Departments of a Physiology, and ${ }^{b}$ Internal Medicine, University of Tübingen, Tübingen, Germany; ${ }^{c}$ Department of

Physiology, University of Khartoum, Khartoum, Sudan

\section{Key Words \\ Calcium • Glucosuria - Hyperglycemia $\cdot$ Phosphate • \\ Proteinuria $\cdot$ Blood pressure}

\begin{abstract}
Background/Aims: Gum arabic (GA) is a $\mathrm{Ca}^{2+}{ }_{-}, \mathrm{Mg}^{2+}$ - and $\mathrm{K}^{+}-$ rich dietary fiber used for the treatment of patients with chronic kidney disease in Middle Eastern countries. In healthy mice, GA treatment increases creatinine clearance, renal $\mathrm{ADH}$ excretion, as well as intestinal and renal excretion of $\mathrm{Mg}^{2+}$ and $\mathrm{Ca}^{2+}$. GA decreases plasma Pi concentration, urinary $\mathrm{Pi}$ and $\mathrm{Na}^{+}$excretion. The present study explored the effects of GA on renal function in diabetic mice. Methods: Metabolic cage experiments were performed on Akita mice $\left(\right.$ akita $\left.^{+-}\right)$, which spontaneously develop insulin deficiency and thus hyperglycemia. Plasma and urinary concentrations of $\mathrm{Na}^{+}, \mathrm{K}^{+}$and $\mathrm{Ca}^{2+}$ were measured by flame photometry (AFM 5051, Eppendorf, Germany), creatinine by the Jaffé method, phosphate photometrically, urea by an enzymatic method, glucose utilizing a glucometer and an enzymatic kit, aldosterone using an RIA, urinary albumin fluorometrically, and blood pressure by the tail-cuff method. Results: GA (10\% in drinking water) significantly increased urinary excretion of $\mathrm{Ca}^{2+}$ and significantly decreased plasma phos-
\end{abstract}

phate and urea concentrations, urinary flow rate, urinary $\mathrm{Na}^{+}$, phosphate and glucose excretion, blood pressure and proteinuria. Conclusions: GA treatment decreases blood pressure and proteinuria in diabetic mice and may thus prove beneficial in diabetic nephropathy.

Copyright $\odot 2012$ S. Karger AG, Basel

\section{Introduction}

Gum arabic (GA), a water-soluble dietary fiber [1] derived from the dried gummy exudates from the stems and branches of Acacia senegal [2], is a polysaccharide based on branched chains of (1-3)-linked $\beta$-D-galactopyranosyl units containing $\alpha$-L-arabinofuranosyl, $\alpha$-L-rhamnopyranosyl, $\beta$-D-glucuronopyranosyl and 4-O-methyl- $\beta$ D-glucuronopyranosyl units [3]. Upon ingestion, GA is fermented in the colon by microorganisms to short-chain fatty acids [4].

GA is considered one of the safest dietary fibers by the US Food and Drug Administration [5]. In Middle Eastern

Omaima Nasir and Anja T. Umbach contributed equally and thus share first authorship.

\section{KARGER}

Fax +4161306 1234

E-Mail karger@karger.ch

www.karger.com
(C) 2012 S. Karger AG, Basel

$1420-4096 / 12 / 0355-0365 \$ 38.00 / 0$

Accessible online at:

www.karger.com/kbr
Florian Lang

Department of Physiology, University of Tübingen

Gmelinstrasse 5

DE-72076 Tübingen (Germany)

Tel. +497071 297 2194, E-Mail florian.lang@uni-tuebingen.de 


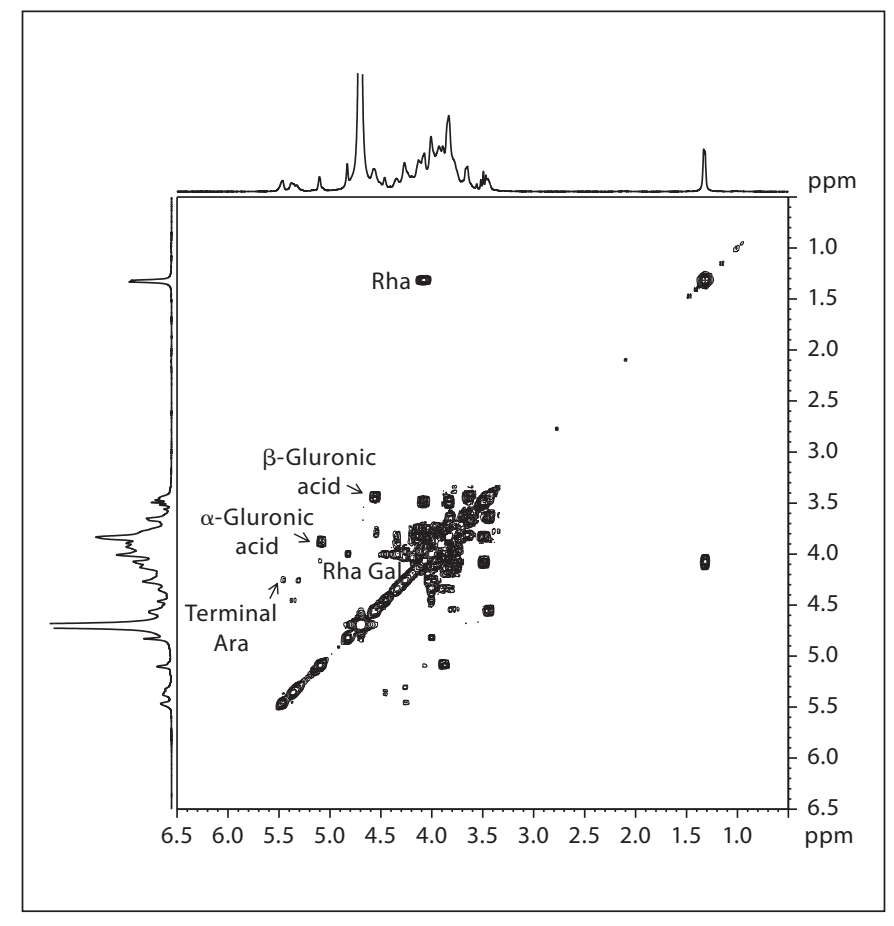

Fig. 1. Structural characterization of GA. COSY HR/MAS NMR spectrum of GA in D2O, $313 \mathrm{~K}$ with labeled cross-peaks for the monosaccharide units.

countries GA is widely used in the treatment of patients with chronic kidney disease and end-stage renal disease [6]. GA was found to increase fecal nitrogen excretion [7], to decrease production of free oxygen radicals [6], and to modestly counteract renal injury following acute gentamicin nephrotoxicity in rats [8]. In healthy mice, GA treatment has been shown to increase creatinine clearance and renal ADH excretion as well as intestinal and renal excretion of $\mathrm{Mg}^{2+}$ and $\mathrm{Ca}^{2+}$ [9]. It has also been shown to lower plasma concentration of $1,25(\mathrm{OH})_{2} \mathrm{D}_{3}$ as well as urinary $\mathrm{P}_{\mathrm{i}}$ and $\mathrm{Na}^{+}$excretion [9].

A major cause of end-stage renal disease is diabetic nephropathy [10]. The present study thus explored the effects of GA on renal function in diabetic mice. To this end, metabolic cage experiments were performed on heterozygous Akita (akita ${ }^{+/}$) mice, which develop spontaneous diabetes due to the gradual destruction of pancreatic $\beta$-cells [11]. It is shown that GA treatment of those mice indeed influences renal function. Most importantly, GA treatment decreased proteinuria, an important parameter for the progression of renal disease [12-18].

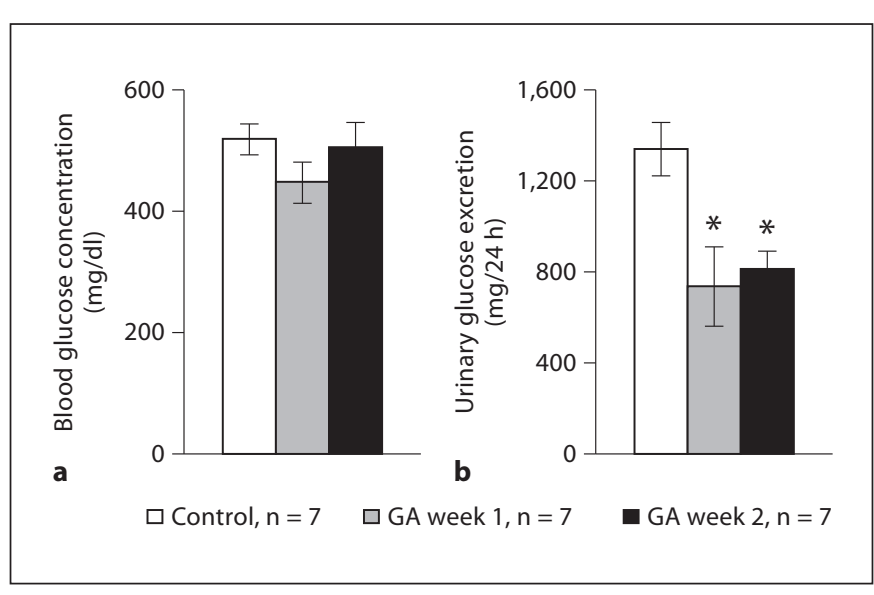

Fig. 2. Effect of GA treatment on blood glucose concentration and urinary glucose excretion of $\mathrm{akita}^{+-}$mice. Arithmetic means \pm SEM of blood glucose concentration (a) and urinary glucose excretion (b) in heterozygous akita ${ }^{+/-}$mice without and with 1 week's or 2 weeks' GA treatment. Asterisk indicates significant difference from control (without GA treatment).

\section{Methods}

\section{Gum Arabic}

GA in powder form was provided as a generous gift from Dar Savanna Ltd., Khartoum, Sudan (www.ssgums.com). The fully natural extract powder with a particle size smaller than $210 \mu \mathrm{m}$ was produced mechanically from wildly grown $A$. senegal trees. The quality conforms to the food and pharmaceutical requirements of the Food and Agriculture Organization of the United Nations (FAO), British pharmacopoeia (BP), United States pharmacopoeia (USP) and the Joint FAO/WHO Expert Committee on Food Additives (JECFA).

Optical rotation was determined on a Perkin Elmer model 341 polarimeter. GA was dissolved in water and measured at $20^{\circ} \mathrm{C}$ to obtain a value of $-28^{\circ}$.

${ }^{1} \mathrm{H}$ HR/MAS NMR spectra of GA was recorded on a Bruker ARX $400-\mathrm{MHz}$ spectrometer at a spinning rate of $4 \mathrm{kHz}$ in a 4-mm double-bearing $\mathrm{ZrO}_{2}$ rotor. The spectrometer was equipped with a deuterium lock setup, which was set on the resonance frequency of $\mathrm{D}_{2} \mathrm{O}$. The $90^{\circ}$ pulse length was set to 10.5 $\mu s$. Spectra were recorded at $313 \mathrm{~K}$ and multiplied by an exponential line broadening function of $\mathrm{lb}=0.5 \mathrm{~Hz}$ prior to Fourier transformation. Spectrum processing was performed using Bruker TOPSPIN 2.0 software. Assignment of the GA proton COSY HR/MAS NMR spectrum was obtained for a number of cross-peaks starting from the anomeric protons. Figure 1 displays the spectrum with the labeled cross-peaks as reported previously [19]. The obtained data is in accordance with JECFA specifications and provides valuable information on the studied sample [20, 21].

\section{Animals}

Experiments were carried out on heterozygous akita ${ }^{+/-}$mice (age: 3-8 months) which spontaneously develop diabetes. Before 


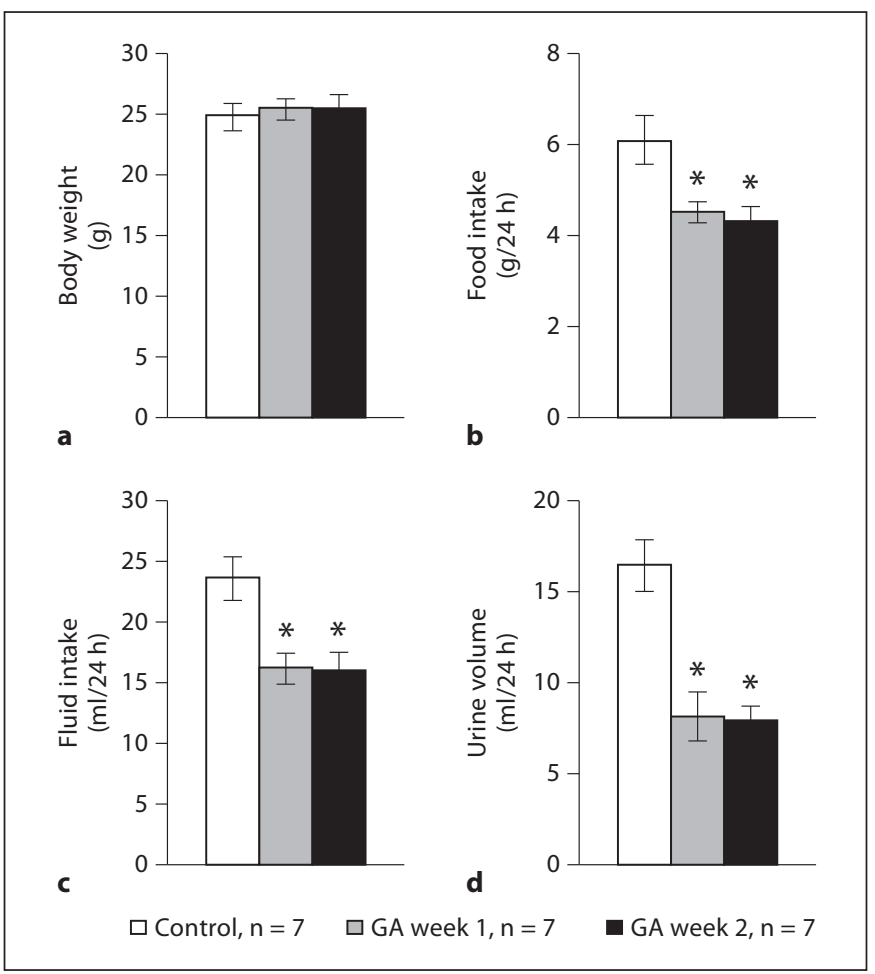

Fig. 3. Effect of GA treatment on body weight, food intake, fluid intake, and urinary output of $a k i t a^{+/-}$mice. Arithmetic means \pm SEM of body weight (a), food intake (b), fluid intake (c) and urinary output (d) in heterozygous akita ${ }^{+-}$mice without and with 1 week's or 2 weeks' GA treatment. Asterisk indicates significant difference from control (without GA treatment).

including the mice in the study the diabetic phenotype was assured by the determination of plasma glucose concentrations. A glucose concentration above $200 \mathrm{mg} / \mathrm{dl}$ was considered as diabetic. The animals were housed under controlled environmental conditions $\left(22-24^{\circ} \mathrm{C}, 50-70 \%\right.$ humidity and a 12 -hour light/dark cycle). Throughout the study the mice had free access to standard pelleted food (Altromin, Lage, Germany) and tap water or GA solution as indicated. All animal experiments were conducted according to the guidelines of the American Physiological Society and the German law for the care and welfare of animals and were approved by local authorities.

\section{GA Treatment}

GA was administered by the addition of $10 \%$ (w/w) GA to the tap drinking water $(100 \mathrm{~g} / \mathrm{l})$. The preparations were refreshed every 3 days during the treatment. The effects of GA administration were investigated before treatment with GA, after 1 week and after 2 weeks of GA treatment. The intake corresponded to a dose of approximately $20 \mathrm{~g} / \mathrm{kg}$ body weight/day.

\section{Collection of Urine}

For the evaluation of renal excretion as well as daily food and fluid intake, the mice were placed individually in metabolic cages

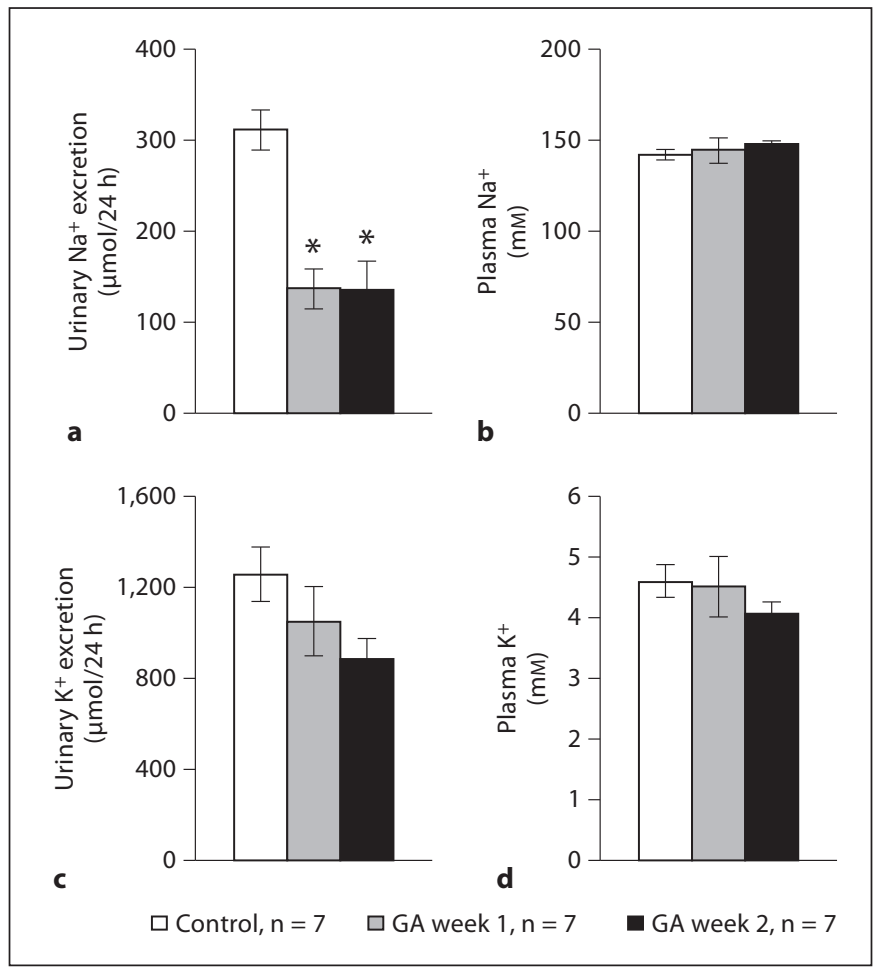

Fig. 4. Effect of GA treatment on urinary excretion and plasma concentration of $\mathrm{Na}^{+}$and $\mathrm{K}^{+}$in $a \mathrm{kita}^{+/-}$mice. Arithmetic means \pm SEM of urinary excretions $(\mathbf{a}, \mathbf{c})$ and plasma concentration (b, d) of $\mathrm{Na}^{+}(\mathbf{a}, \mathbf{b})$ and $\mathrm{K}^{+}(\mathbf{c}, \mathbf{d})$ in heterozygous a $\mathrm{kita}^{+/-}$mice without and with 1 week's or 2 weeks' GA treatment. Asterisk indicates significant difference from control (without GA treatment).

(Techniplast, Hohenpeissenberg, Germany) for $24 \mathrm{~h}$ and urine was collected with free access to fluid as well as standard diet. Collections were performed at baseline with tap water, and with GAcontaining drinking water for 1 or 2 weeks. The inner wall of the metabolic cages was siliconized, and urine was collected under water-saturated oil.

\section{Determination of Plasma and Urinary Concentrations}

To obtain blood specimens, the animals were lightly anesthetized with diethylether (Roth, Karlsruhe, Germany), and approximately $130 \mu$ l of blood was withdrawn into heparinized capillaries by puncturing the retro-orbital plexus.

The plasma and urinary concentrations of $\mathrm{Na}^{+}, \mathrm{K}^{+}$and $\mathrm{Ca}^{2+}$ were measured by flame photometry (AFM 5051, Eppendorf, Germany) or by a photometric method according to the manufacturer's instructions (dri-chem clinical chemistry analyzer FUJI FDC 3500i, Sysmex, Norsted, Germany). Urinary creatinine concentrations were measured using a kinetic Jaffé method. The plasma and urinary phosphate concentrations were measured photometrically using kits from Roche Diagnostics (Mannheim, Germany). Plasma urea was measured by an enzymatic method (Lehmann, Berlin, Germany). 


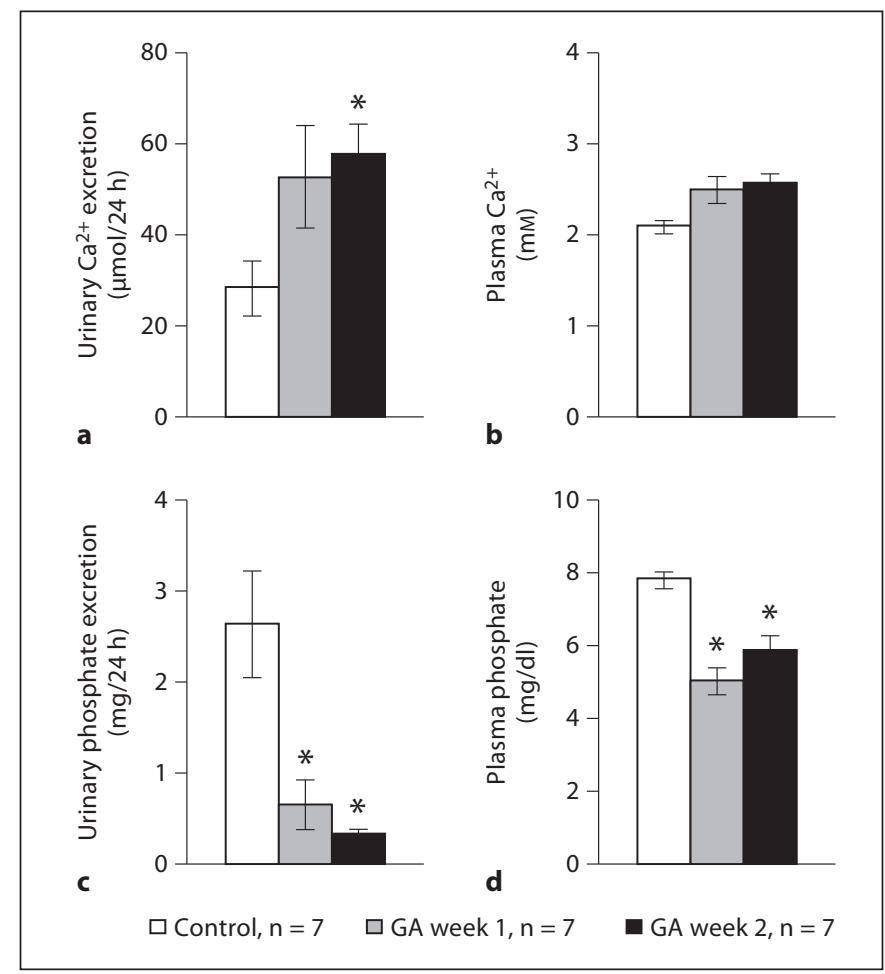

Fig. 5. Effect of GA treatment on urinary excretion and plasma concentration of $\mathrm{Ca}^{2+}$ and phosphate in $\mathrm{akita}^{+/-}$mice. Arithmetic means \pm SEM of urinary excretion $(\mathbf{a}, \mathbf{c})$ and plasma concentration $(\mathbf{b}, \mathbf{d})$ of $\mathrm{Ca}^{2+}(\mathbf{a}, \mathbf{b})$ and phosphate $(\mathbf{c}, \mathbf{d})$ in heterozygous $a_{k i t a}{ }^{+/-}$mice without and with 1 week's or 2 weeks' GA treatment. Asterisk indicates significant difference from control (without GA treatment).

The blood glucose concentration was determined utilizing a glucometer (Accutrend, Roche, Mannheim, Germany). The urinary glucose concentration was determined utilizing a commercial enzymatic kit (Gluco-quant, Roche Diagnostics, Mannheim, Germany). Plasma aldosterone concentration was measured using an RIA kit (Demeditec, Kiel, Germany).

Urinary albumin was measured fluorometrically using the albumin-sensitive dye albumin blue 580 at 595-nm excitation and 642-nm emission on a Wallac counter (Victor 1420) according to the manufacturer's instructions (microfluoral, Progen, Heidelberg, Germany). Standard curves were generated with mouse albumin (Sigma, Schnelldorf, Germany), and measurements were performed within the linear range $(0-156 \mathrm{mg} / \mathrm{l})$.

\section{Blood Pressure Measurements}

Systolic arterial blood pressure was determined by the tail-cuff method (IITC, Model 179, Woodland Hills, Calif., USA). Application of this method requires certain precautions to reduce the stress of the animals, including appropriate training of the mice over multiple days and adequate prewarming to dilate the tail artery. The animals were placed in a heated chamber at an ambient temperature of $30-32^{\circ} \mathrm{C}$. Animal blood pressure traces were re-
Table 1. Arithmetic means \pm SEM $(n=3-4)$ of the indicated parameters determined before (control) and following treatment of akita $^{+/-}$mice with GA for 7 or for 14 days

\begin{tabular}{lccr}
\hline & Control & $\begin{array}{l}7 \text { days' } \\
\text { treatment }\end{array}$ & $\begin{array}{l}14 \text { days' } \\
\text { treatment }\end{array}$ \\
\hline $\mathrm{FE}\left(\mathrm{Na}^{+}\right), \%$ & $1.05 \pm 0.58$ & $0.07 \pm 0.01$ & $0.03 \pm 0.02$ \\
$\mathrm{FE}\left(\mathrm{K}^{+}\right), \%$ & $20.11 \pm 7.02$ & $5.11 \pm 1.41$ & $12.31 \pm 7.27$ \\
$\mathrm{FE}($ urea $), \%$ & $222.15 \pm 67.10$ & $36.33 \pm 7.55^{*}$ & $30.75 \pm 9.8^{*}$ \\
\hline
\end{tabular}

${ }^{*} \mathrm{p}<0.05 . \mathrm{FE}=$ Fractional excretion.

corded in one session until the deviation of a minimum of 5 traces was lower than $5 \mathrm{~mm} \mathrm{Hg}$. The readings from 3 days were then averaged to obtain a mean blood pressure under the respective treatment. All recordings and data analysis were done using a computerized data acquisition system and software (PowerLab 400 and Chart 5, both AdInstruments, Colorado Springs, Colo., USA). All measurements were performed by the same person during a defined time.

\section{Statistical Analysis}

Data are provided as arithmetic means \pm SEM, and $n$ represents the number of independent experiments. Data were tested for significance using the paired two-tailed Student $t$ test when two-sample means were tested. $\mathrm{p}<0.05$ was considered statistically significant.

\section{Results}

As described earlier [11], heterozygous akita ${ }^{+/-}$mice developed marked and statistically significant hyperglycemia (fig. 2). Treatment of the $a k i t a^{+/-}$mice with GA tended to slightly decrease the plasma glucose concentration, an effect, however, not reaching statistical significance. The treatment significantly reduced the urinary glucose excretion (fig. 2).

Within the observed treatment period of up to 2 weeks, GA did not significantly modify the body weight of the akita ${ }^{+/-}$mice (fig. 3) despite a significant decrease of food intake following GA treatment (fig. 3). Similarly, fluid intake and as a result urinary output were decreased following GA treatment of the $\mathrm{akita}^{+/-}$mice (fig. 3).

The decrease of glucosuria and urinary flow rate of the $a k i t a^{+/-}$mice was paralleled by a significantly decreased urinary $\mathrm{Na}^{+}$excretion (fig. 4; table 1). Urinary $\mathrm{K}^{+}$excretion tended to decrease following GA treatment, an effect, however, not reaching statistical significance (fig. 4; table 1). Neither plasma $\mathrm{Na}^{+}$concentration nor plasma K${ }^{+}$ 
Fig. 6. Effect of GA treatment on urinary creatinine and albumin excretion of aki$\mathrm{ta}^{+/-}$mice. Arithmetic means \pm SEM of urinary creatinine excretion (c), urinary albumin excretion (a) and urinary albumin excretion over body weight (b) in heterozygous $a k i t a^{+/-}$mice without and with 1 week's or 2 weeks' GA treatment. Asterisk indicates significant difference from control (without GA treatment).

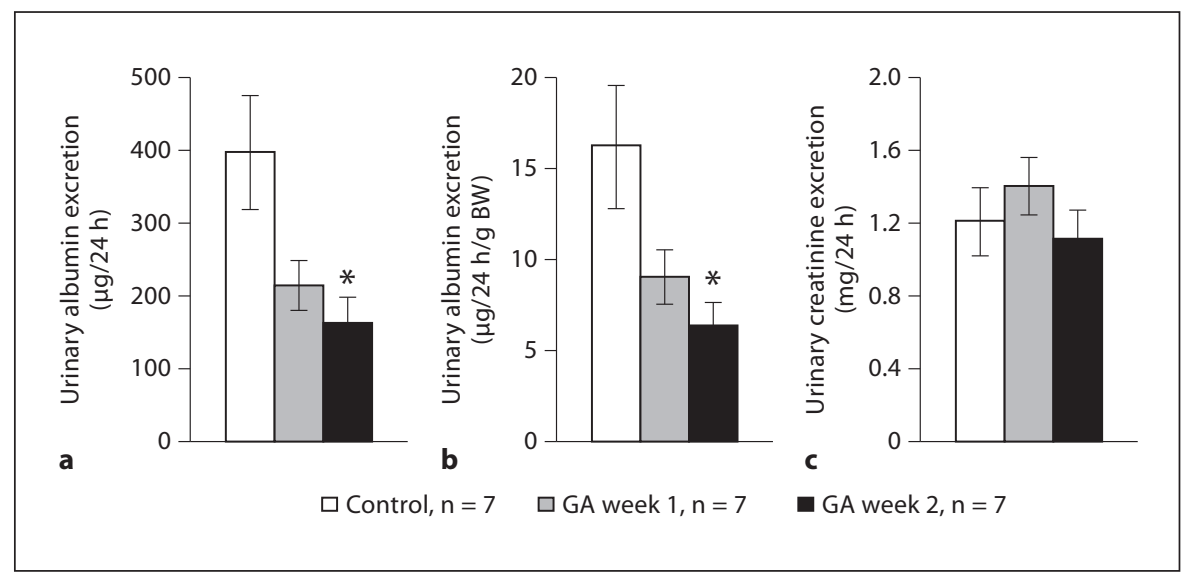

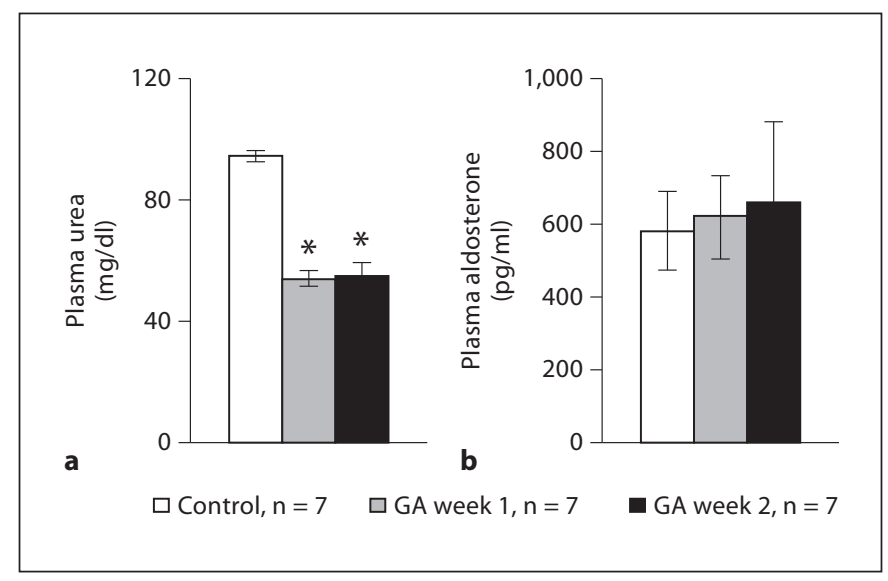

Fig. 7. Effect of GA treatment on plasma urea and aldosterone concentration of $\mathrm{akita}^{+/-}$mice. Arithmetic means \pm SEM of plasma urea (a) and aldosterone (b) concentration in heterozygous akita $^{+/-}$mice without and with 1 week's or 2 weeks' GA treatment. Asterisk indicates significant difference from control (without GA treatment).

concentration of the $a k i t a^{+/-}$mice were significantly modified by the GA treatment (fig. 4).

GA treatment of $a k i t a^{+/-}$mice significantly increased the urinary excretion of $\mathrm{Ca}^{2+}$ (fig. 5). Plasma Ca ${ }^{2+}$ concentration tended to increase following GA treatment, an effect, however, not reaching statistical significance (fig. 5). GA treatment of $a k i t a^{+/-}$mice was followed by a profound and significant decrease of plasma phosphate concentration paralleled by a significant decrease of urinary phosphate excretion (fig. 5).

As illustrated in figure 6, the diabetic akita ${ }^{+/-}$mice developed albuminuria. Surprisingly, the albuminuria was significantly decreased by GA treatment. Urinary creati-

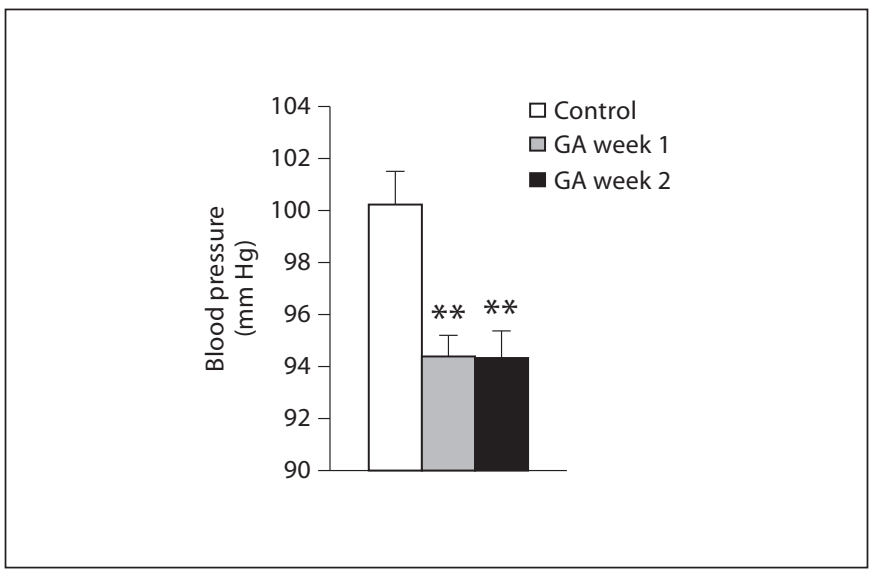

Fig. 8. Effect of GA treatment on arterial blood pressure. Arithmetic means \pm SEM $(n=9-11)$ of arterial blood pressure in heterozygous $\mathrm{akita}^{+/-}$mice without and with 1 week's or 2 weeks' GA treatment. ${ }^{* *} \mathrm{p}<0.01$ vs. control.

nine excretion remained constant during GA treatment (fig. 6).

Plasma urea concentration and fractional urea excretion decreased in GA-treated k kita $^{+/-}$mice (fig. 7; table 1). Plasma aldosterone concentration was not significantly modified by GA treatment (fig. 7).

As shown in figure 8, GA treatment was followed by a marked and significant decrease of arterial blood pressure.

In wild-type mice, GA treatment significantly reduced urinary $\mathrm{Na}^{+}$excretion (table 2). 
Table 2. Arithmetic means \pm SEM $(n=4-5)$ of the indicated parameters determined before (control) and following treatment of wild-type mice with GA for 7 or for 14 days

\begin{tabular}{|c|c|c|c|}
\hline & Control & 7 days' treatment & 14 days' treatment \\
\hline Body weight, g & $28.11 \pm 1.66$ & $27.93 \pm 2.13$ & $27.01 \pm 2.09$ \\
\hline Food intake, g/24 h & $3.66 \pm 0.52$ & $3.88 \pm 0.16$ & $3.81 \pm 0.24$ \\
\hline Fluid intake, $\mathrm{g} / 24 \mathrm{~h}$ & $5.59 \pm 0.28$ & $6.08 \pm 0.59$ & $5.83 \pm 0.59$ \\
\hline Urine output, $\mathrm{ml} / 24 \mathrm{~h}$ & $1.05 \pm 0.25$ & $1.1 \pm 0.26$ & $1.04 \pm 0.34$ \\
\hline $\mathrm{Na}^{+}$serum, $\mathrm{mmol} / \mathrm{l}$ & $146.54 \pm 1.14$ & $143.35 \pm 1.13$ & $146.78 \pm 1.29$ \\
\hline $\mathrm{K}^{+}$serum, $\mathrm{mmol} / \mathrm{l}$ & $4.14 \pm 0.23$ & $4.27 \pm 0.15$ & $3.82 \pm 0.29$ \\
\hline $\mathrm{Ca}^{2+}$ serum, $\mathrm{mmol} / \mathrm{l}$ & $2.24 \pm 0.04$ & $2.52 \pm 0.19$ & $2.40 \pm 0.08$ \\
\hline Pi serum, mmol/l & $1.61 \pm 0.15$ & $1.44 \pm 0.46$ & $1.03 \pm 0.11^{*}$ \\
\hline Urine $\mathrm{Na}^{+}, \mu \mathrm{mol} / 24 \mathrm{~h}$ & $122.15 \pm 15.20$ & $65.82 \pm 7.01^{* *}$ & $50.38 \pm 9.04^{* *}$ \\
\hline $\mathrm{FE}\left(\mathrm{Na}^{+}\right), \%$ & $1.19 \pm 0.09$ & $0.62 \pm 0.16^{* *}$ & $0.45 \pm 0.16^{*}$ \\
\hline Urine $\mathrm{K}^{+}, \mu \mathrm{mol} / 24 \mathrm{~h}$ & $541.93 \pm 75.96$ & $591.53 \pm 49.90$ & $539.11 \pm 88.74$ \\
\hline $\mathrm{FE}\left(\mathrm{K}^{+}\right), \%$ & $185.2 \pm 12.34$ & $183.22 \pm 29.26$ & $210.80 \pm 64.61$ \\
\hline Urine $\mathrm{Ca}^{2+}, \mu \mathrm{mol} / 24 \mathrm{~h}$ & $18.23 \pm 1.56$ & $29.30 \pm 3.03$ & $23.91 \pm 2.94$ \\
\hline $\mathrm{FE}\left(\mathrm{Ca}^{2+}\right), \%$ & $14.22 \pm 1.93$ & $14.9 \pm 2.77$ & $16.46 \pm 1.26$ \\
\hline Urine $\mathrm{Pi}, \mu \mathrm{mol} / 24 \mathrm{~h}$ & $6.22 \pm 2.97$ & $2.81 \pm 0.4^{*}$ & $2.77 \pm 0.70^{*}$ \\
\hline $\mathrm{FE}(\mathrm{Pi}), \%$ & $2.71 \pm 0.33$ & $3.30 \pm 1.20$ & $4.46 \pm 1.79$ \\
\hline Creatinine clearance, $\mu \mathrm{l} / \mathrm{min}$ & $52.95 \pm 7.48$ & $60.46 \pm 11.1$ & $56.54 \pm 11.65$ \\
\hline Urine creatinine, $\mu \mathrm{mol} / 24 \mathrm{~h}$ & $5.78 \pm 0.84$ & $6.89 \pm 0.98$ & $5.9 \pm 1.14$ \\
\hline
\end{tabular}

${ }^{*} \mathrm{p}<0.05,{ }^{* *} \mathrm{p}<0.01$ vs. control. FE $=$ Fractional excretion.

\section{Discussion}

The present study reveals novel effects of GA. In diabetic heterozygous a kita ${ }^{+/}$mice, GA treatment decreased glucosuria without appreciably influencing the plasma glucose concentration. Possibly, GA increased renal tubular glucose transport. Despite the decrease of urinary glucose loss, the plasma glucose concentration was not significantly modified by GA treatment. Presumably, the decreased food intake compensated for the decreased urinary glucose loss and thus, neither plasma glucose concentration nor body weight was significantly modified by GA treatment.

The reduced glucosuria might have contributed to the decrease of urinary volume and urinary $\mathrm{Na}^{+}, \mathrm{K}^{+}$and urea excretion. Glucosuria imposes an osmotic diuresis with subsequent renal loss of electrolytes [22]. Moreover, GA treatment increases the release of $\mathrm{ADH}$ [9], which may have contributed to the decreased fluid, $\mathrm{Na}^{+}$and urea excretion.

The antinatriuresis was paralleled by calciuria, which is presumably secondary to enhanced $\mathrm{Ca}^{2+}$ intake. GA is rich in $\mathrm{Ca}^{2+}$ salts (table 3) [3]. Accordingly, a calciuric effect of GA treatment has been reported earlier in healthy mice [9]. In this earlier study the increased uptake of cal- cium was followed by suppression of the secretion of the biologically active $1,25(\mathrm{OH})_{2} \mathrm{D}_{3}$ and a tendency of PTH plasma concentration to similarly decrease [9]. The decrease of plasma PTH and $1,25(\mathrm{OH})_{2} \mathrm{D}_{3}$ concentrations is expected to reduce renal tubular $\mathrm{Ca}^{2+}$ reabsorption and thus presumably contributes to or even accounts for the calciuria [23, 24].

A decrease of the plasma $1,25(\mathrm{OH})_{2} \mathrm{D}_{3}$ concentration is expected to decrease intestinal phosphate absorption, which may account for the decline of plasma phosphate concentration. The hypophosphatemia is in turn expected to result in antiphosphaturia, which has indeed been observed in healthy [9] and diabetic mice. The antiphosphaturia would be further fostered by reduced PTH plasma levels [25].

The most striking observation was the marked decrease of albuminuria following GA treatment. The decrease of albuminuria could have been due to a decrease of blood pressure. In an earlier study [9], we did not observe a significant effect of GA treatment on plasma aldosterone concentration or blood pressure of healthy mice. In the present study on diabetic mice, however, GA did significantly decrease blood pressure. Moreover, an antihypertensive effect of GA has been demonstrated earlier in humans [26]. The effect of GA on blood pressure could at least in part be 
Table 3. Properties and composition of GA according to the manufacturer

\begin{tabular}{lc}
\hline Form & Powder \\
\hline Particle size & $<250 \mu \mathrm{m}$ \\
Viscosity of 20\% solution & $70-110 \mathrm{cP}$ \\
pH of 20\% solution & $4.1-4.8$ \\
Specific rotation & $\left(\right.$ oc) $\mathrm{D} 25 \mathrm{c}\left(-26^{\circ}\right)$ to $\left(-35^{\circ}\right)$ \\
Moisture & $<13 \%$ \\
Total ash & $<4 \%$ \\
Acid-insoluble residue & $<1.0 \%$ \\
Starch or dextrin & Negative \\
Tannin bearing gums & Negative \\
Arsenic & $<1.0 \mathrm{mg} / \mathrm{kg}$ \\
Lead & $<2.0 \mathrm{mg} / \mathrm{kg}$ \\
Cadmium & $<1.0 \mathrm{mg} / \mathrm{kg}$ \\
Mercury & $0.05 \mathrm{mg} / \mathrm{kg}$ \\
Antimony & $<1.0 \mathrm{mg} / \mathrm{kg}$ \\
Tin & $<40 \mathrm{mg} / \mathrm{kg}$ \\
Copper & $<20 \mathrm{mg} / \mathrm{kg}$ \\
Total dietary fiber (as is) & $>85 \%$ \\
Total dietary fiber (dry weight) & $>90 \%$ \\
\hline Nutritional information (approximate & values per $100 \mathrm{~g})$ \\
Energy & $200 \mathrm{kcal}$ \\
Protein & $1.9 \mathrm{~g}$ \\
Available carbohydrates & $<0.1 \mathrm{~g}$ \\
Fat & $0.1 \mathrm{~g}$ \\
Soluble dietary fiber & $85.5 \mathrm{~g}$ \\
Soluble dietary fiber (dry basis) & $94 \mathrm{~g}$ \\
Cholesterol & $<1 \mathrm{mg}$ \\
Sodium & $14 \mathrm{mg}$ \\
Calcium & $1,074 \mathrm{mg}$ \\
Potassium & $914 \mathrm{mg}$ \\
Magnesium & $390 \mathrm{mg}$ \\
Iron & $1.0 \mathrm{mg}$ \\
\hline & \\
\hline &
\end{tabular}

due to enhanced $\mathrm{Ca}^{2+}$ intake, which has been shown to lower blood pressure, an effect attributed in part to stimulation of the $\mathrm{Ca}^{2+}$-sensing receptor with subsequent inhibition of the $\mathrm{Na}^{+}, \mathrm{K}^{+}, 2 \mathrm{Cl}^{-}$cotransport in the thick ascending limb [27] or triggering of vasodilation [28].

The present study does not rule out antiproteinuric effects of GA treatment involving additional mechanisms unrelated to blood pressure. GA treatment was further associated with an increased creatinine clearance [9]. The mechanisms involved in the influence of GA treatment on glomerular function remain elusive. The fermentation of GA by intestinal bacteria leads to the formation of several degradation products including short-chain fatty acids [29]. Accordingly, GA treatment has previously been shown to enhance the serum butyrate concentration in healthy subjects [30]. Infusion of D,L-3-hydroxybutyric acid and sodium D,L-3-hydroxybutyrate have in turn been shown to increase the glomerular filtration rate and renal blood flow in humans [31]. It is tempting to speculate that the enhanced butyrate formation influences glomerular function during GA treatment.

GA is used in Middle Eastern countries for the treatment of patients with chronic and end-stage kidney disease [6]. The present data indeed disclose some effects of GA treatment, which may be beneficial for patients with renal disease. First, the decrease of proteinuria is expected to delay the progression of renal disease [12]. Second, the decrease of plasma phosphate concentration increases the plasma concentration of ionized $\mathrm{Ca}^{2+}$ and thus counteracts hyperparathyroidism, a major pathophysiological parameter in advanced renal disease [32-34]. Third, an increase in creatinine clearance, as has been observed earlier [9], counteracts the decline of renal excretory function. Our data are thus indeed suggestive of a favorable influence of GA treatment on renal function in diabetic individuals. It should, however, be pointed out that the phenotype of the $a k i t a^{+-}$mice is not that of fully developed diabetic nephropathy. Rather, the renal function reflects that of early diabetes.

At least in theory, the composition and chemical property and thus the biological effects of GA may vary. It remains to be shown whether other preparations of GA are similarly effective.

In conclusion, this present study reveals several effects of GA treatment, which may delay the progression to renal failure in diabetes. Most importantly, GA treatment decreases proteinuria, lowers plasma phosphate concentration and increases the glomerular filtration rate.

\section{Acknowledgements}

The authors are grateful to Helen Yeman and Prof. Dr. Klaus Albert (Institute of Organic Chemistry, University of Tübingen, Germany) for providing the optical rotation data and NMR spectra of GA. This work was supported by a DAAD fellowship (O.N.).

\section{Disclosure Statement}

The authors of this manuscript state that they have no conflicts to declare and that the results presented in this paper have not been published previously in whole or in part. 


\section{References}

$>1$ Tiss A, Carrière F, Verger R: Effects of gum $>12$ Abbate M, Zoja C, Remuzzi G: How does arabic on lipase interfacial binding and activity. Anal Biochem 2001;294:36-43.

$\checkmark 2$ Younes H, Garleb K, Behr S, Remesy C, Demigne C: Fermentable fibers or oligosaccharides reduce urinary nitrogen excretion by increasing urea disposal in the rat cecum. J Nutr 1995;125:1010-1016.

3 Deckwer WD, Dill B, Eisenbrand E, Bornscheuer U, Pühler A, Heiker FR, Kirschning A, Schreier P, Fugmann B, Pohnert G, Gamse T, Hulpke H: Römpp Online. Stuttgart, Thieme, 2006.

$>4$ Phillips GO: Acacia gum (Gum Arabic): a nutritional fibre; metabolism and calorific value. Food Addit Contam 1998;15:251-264.

$\checkmark 5$ Anderson DM: Evidence for the safety of gum arabic (Acacia senegal (L.) Willd.) as a food additive - a brief review. Food Addit Contam 1986;3:225-230.

$\checkmark 6$ Al Majed AA, Mostafa AM, Al Rikabi AC, Al Shabanah OA: Protective effects of oral arabic gum administration on gentamicin-induced nephrotoxicity in rats. Pharmacol Res 2002;46:445-451.

7 Bliss DZ, Stein TP, Schleifer CR, Settle RG: Supplementation with gum arabic fiber increases fecal nitrogen excretion and lowers serum urea nitrogen concentration in chronic renal failure patients consuming a lowprotein diet. Am J Clin Nutr 1996;63:392398.

$>8$ Ali BH, Al Qarawi AA, Haroun EM, Mousa HM: The effect of treatment with gum arabic on gentamicin nephrotoxicity in rats: a preliminary study. Ren Fail 2003;25:15-20.

-9 Nasir O, Artunc F, Saeed A, Kambal MA, Kalbacher H, Sandulache D, Boini KM, Jahovic N, Lang F: Effects of gum arabic (Acacia senegal) on water and electrolyte balance in healthy mice. J Ren Nutr 2008;18:230-238.

10 Schernthaner G: Kidney disease in diabetology: lessons from 2007. Nephrol Dial Transplant 2008;23:1112-1115.

$>11$ Hong EG, Jung DY, Ko HJ, Zhang Z, Ma Z, Jun JY, Kim JH, Sumner AD, Vary TC, Gardner TW, Bronson SK, Kim JK: Nonobese, insulin-deficient Ins2Akita mice develop type 2 diabetes phenotypes including insulin resistance and cardiac remodeling. Am J Physiol Endocrinol Metab 2007;293:E1687E1696. proteinuria cause progressive renal damage? J Am Soc Nephrol 2006;17:2974-2984.

13 Agarwal R: Vitamin D, proteinuria, diabetic nephropathy, and progression of CKD. Clin J Am Soc Nephrol 2009;4:1523-1528.

14 Agrawal V, Marinescu V, Agarwal M, McCullough PA: Cardiovascular implications of proteinuria: an indicator of chronic kidney disease. Nat Rev Cardiol 2009;6:301-311.

15 Bianchi S, Bigazzi R, Campese VM: Intensive versus conventional therapy to slow the progression of idiopathic glomerular diseases. Am J Kidney Dis 2010;55:671-681.

16 Kalaitzidis RG, Bakris GL: Should proteinuria reduction be the criterion for antihypertensive drug selection for patients with kidney disease? Curr Opin Nephrol Hypertens 2009;18:386-391.

$>17$ Levey AS, Cattran D, Friedman A, Miller WG, Sedor J, Tuttle K, Kasiske B, Hostetter T: Proteinuria as a surrogate outcome in CKD: report of a scientific workshop sponsored by the National Kidney Foundation and the US Food and Drug Administration. Am J Kidney Dis 2009;54:205-226.

18 Staples A, Wong C: Risk factors for progression of chronic kidney disease. Curr Opin Pediatr 2010;22:161-169.

19 McIntyre DD, Ceri H, Vogel HJ: Nuclear magnetic resonance studies of the heteropolysaccharides alginate, gum arabic and gum xanthan. Starch/Stärke 1996;48:285291.

20 Anderson DMW, Weiping W: The characterization of gum arabic (Acacia senegal) samples from Uganda. Food Hydrocolloids 1991; 5:297-306.

21 Anderson DMW, Miller JRA, Weiping W: Gum Arabic (Acacia senegal) from Niger comparison with other sources and potential agroforestry development. Biochem Syst Ecol 1991;19:447-452.

22 Lang F: Osmotic diuresis. Ren Physiol 1987; 10:160-173.

23 Friedman PA: Mechanisms of renal calcium transport. Exp Nephrol 2000;8:343-350.
24 Hoenderop JG, Nilius B, Bindels RJ: Molecular mechanism of active $\mathrm{Ca}^{2+}$ reabsorption in the distal nephron. Annu Rev Physiol 2002; 64:529-549.

25 Murer H, Biber J: A molecular view of proximal tubular inorganic phosphate $(\mathrm{Pi})$ reabsorption and of its regulation. Pflügers Arch 1997;433:379-389.

26 Al Mosawi AJ: The challenge of chronic renal failure in the developing world: possible use of acacia gum. Pediatr Nephrol 2002;17:390391.

27 Jung J, Foroud TM, Eckert GJ, Flury-Wetherill L, Edenberg HJ, Xuei X, Zaidi SA, Pratt $\mathrm{JH}$ : Association of the calcium-sensing receptor gene with blood pressure and urinary calcium in African-Americans. J Clin Endocrinol Metab 2009;94:1042-1048.

28 Weston AH, Absi M, Ward DT, Ohanian J, Dodd RH, Dauban P, Petrel C, Ruat M, Edwards G: Evidence in favor of a calciumsensing receptor in arterial endothelial cells: studies with calindol and Calhex 231. Circ Res 2005;97:391-398.

29 Bliss DZ: Dietary fiber in conservative management of chronic renal failure. Pediatr Nephrol 2004; 19:1069-1070.

30 Matsumoto N, Riley S, Fraser D, Al Assaf S, Ishimura E, Wolever T, Phillips GO, Phillips AO: Butyrate modulates TGF-betal generation and function: potential renal benefit for Acacia(sen) SUPERGUM (gum arabic)? Kidney Int 2006;69:257-265.

-31 Fioretto P, Trevisan R, Velussi M, Cernigoi A, De Riva C, Bressan M, Doria A, Pauletto N, Angeli P, De Dona C: Glomerular filtration rate is increased in man by the infusion of both D,L-3-hydroxybutyric acid and sodium D,L-3-hydroxybutyrate. J Clin Endocrinol Metab 1987;65:331-338.

32 Albaaj F, Hutchison A: Hyperphosphataemia in renal failure: causes, consequences and current management. Drugs 2003;63: 577-596.

33 Silver J, Levi R: Cellular and molecular mechanisms of secondary hyperparathyroidism. Clin Nephrol 2005;63:119-126.

34 Cozzolino M, Brancaccio D, Gallieni M, Slatopolsky E: Pathogenesis of vascular calcification in chronic kidney disease. Kidney Int 2005;68:429-436. 